\title{
Effects of CS682, a Fermentation Product of Korean Soil Bacteria, on Growth Performance in Chickens and Pigs
}

\author{
Hu Kyung Kim, Se Eun Kim, Kyung Mi Shim², Jong-Choon Kim', Chun-Sik Bae', Seok Hwa Choi ${ }^{3}$ \\ and Seong Soo Kang *
}

Livestock and Veterinary Service, Suwon, Gyeong gi do, Korea
${ }^{1}$ College of Veterinary Medicine, Chonnam National University, Gwangiu 500-757, Korea
${ }^{2}$ Department of Radidogy, Nambu University, Gwangiu 506-706, Korea
${ }^{3}$ College of Veterinary Medicine, Chungbuk National University, Cheongiu 361-763, Korea

Received November 26, 2009 / Accepted January 13, 2010

\begin{abstract}
Antibiotics in veterinary medicine have been used to treat disease, promote growth rate and improve feed efficiency. However, alternative sources are needed because of of bacterial resistance to antibiotics and residues of antibiotics. The present study was carried out to evaluate the effect of CS682, a fermentation product of Korean soil bacteria, on safety, growth rate and feed efficiency, and to evaluate its value as an alternative for antibiotics used as a feed additive. Two dosages of CS682 (0.1\% and 1\%) were fed to chickens for 28 days. The results showed that, when compared to chickens in the control group, growth and feed efficiency was improved. Also, mortality, hematology, general clinical signs and necropsy were examined. Chickens in the treatment groups showed no adverse effects. A total of 72 weaning pigs were used to confirm the effects of CS682 at one dose level (0.1\%) regarding feed efficiency. Supplementation with $0.1 \%$ CS682 also resulted in improved weight gain and feed efficiency ratio. Based on these results, CS682 may be effective in improving feed efficiency safely as a feed additive.
\end{abstract}

Key words : Growth promoter, CS682, chicken, pig

\section{서 론}

최근 경제성장과 삶의 질 개선으로 식품산업이 비약적으로 발전하고 있으며, 고급 축산물에 대한 수요 증가로 축산업과 동물식품 산업이 급성장하고 있는 추세이다. 2008년 통계자료 에 따르면, 국내에서는 약 290 만 마리의 소와 10,300 만 마리의 닭, 그리고 930만 마리의 돼지가 사육되고 있으며[21], 미국에 서는 소가 약 10,400-11,000만 마리, 닭이 약 75-86억 마리, 돼지 가 약 6,000-9,200만 마리, 그리고 칠면조가 약 27,500-29,200만 마리 사육되고 있다[2,24]. 현대 축산업이 경제성 극대화를 추 구하는 대규모 집약적 사육 형태로 되어감에 따라 질병에 대 한 노출 가능성과 질병 전파의 위험성 또한 더욱 높아지게 되었으며, 이러한 이유에서 질병의 예방과 치료를 위해 사육 환경의 개선보다는 사료 내 항생제의 첨가나 백신 접종 등의 방법이 사용되어 왔다.

1928년 플레밍(Alexander Fleming)에 의해 발견된 항생제 는 항균활성을 나타내는 천연 또는 합성 화학물질을 말하며, 질병치료와 성장촉진 및 사료효율 개선을 목적으로 동물에 사용하고 있다[1,18]. 일반적으로 돼지 사육에서는 질병예방과 성장촉진 목적으로 치료농도 이하(subtherapeutic levels)의

*Corresponding author

Tel : +82-62-530-2877, Fax : +82-62-530-2809

E-mail : vetkang@chonnam.ac.kr
수준으로 항생제를 사료에 첨가하여 급여하고 있다. Dewey 등 $[8,9]$ 에 따르면, 돼지의 자돈사료에서 $90 \%$ 이상, 성장기 사 료에서 $75 \%$ 이상, 그리고 비육돈 사료에서 $50 \%$ 이상이 항생제 를 포함하고 있다고 보고하고 있다. 돼지에서 항생제의 사료 내 급여는 3.3-8.8\% 의 체중증가와 $7 \%$ 의 사료효율 개선을 나타 내어 치료농도 이하의 항생제는 가축의 성장과 건강에 유용하 다고 인식되어 왔다[7,10].

그러나 항생제 내성균 발생 및 축산물 내 항생제 잔류로 인한 인체로의 전이와 같은 문제점이 부각되면서 국내외적으 로 항생제의 사용을 엄격하게 규제하고 있다. 따라서 최근 이 를 대신할 수 있는 대체물질에 대한 연구가 광범위하게 이루 어지고 있다. 항생제를 대신할 수 있는 대체물질로는 생균제, 효소제, 유기산, 올리고당, 항산화제 및 기타 기능성 물질들이 있다. 그 중 생균제는 살아있는 유익한 미생물을 함유한 제제 로서 동물의 장내에 정착하여 다른 병원성 미생물과 경쟁적 배제를 통해 유해 미생물의 성장을 억제하고 섭취한 사료의 소화와 흡수를 도와줌으로써 동물의 성장을 촉진하고 사료효 율을 증가시켜 주는 약제로 알려져 있고, 이는 생균, 사균 및 발효물을 포함한다[22].

본 연구에서 사용된 시험 물질인 CS682는 조선대학교에서 개발한 국내 토양미생물인 Norcardia sp. CS682의 액상 발효액 을 동결건조 후 성상, 물성개선 및 제품함량을 고려하여 옥수 수전분을 첨가하여 분말로 만든 물질이다. 약리학적 시험결 
과, 강한 항균 활성을 가지고 있으며, 특히 메치실린 저항성 Staphylococcus aureus에 대해 강력한 항균활성을 나타내었고, 여러 시험결과에서 항산화 활성이 확인되었다[29]. 이외에도 암 세포 분화유도 활성[19] 및 낮은 세포 독성[29]이 보고되었다.

이와 같은 특성을 고려해 볼 때, CS682의 항생제 대체 사료 첨가제로서의 효과가 기대됨에 따라, 본 연구에서는 육계와 이유자돈에서 CS682의 안전성, 성장률, 사료효율 등을 평가하 여 효과적이고 안전한 사료첨가제로서의 가능성을 알아보고 자 하였다.

\section{재료 및 방법}

\section{시험동물 및 사육환경}

\section{육계}

2 일령 코브종 병아리 100 수를 공시하여 기본 배합 사료를 급여한 대조군에 34 수, CS682를 $0.1 \%$ 와 $1 \%$ 를 첨가한 사료 급 여군에 각각 33 수를 배정하였다. 시험 기간은 28 일로 $32^{\circ} \mathrm{C}$ 전 후, 상대습도 $50-70 \%, 12$ 시간의 명암주기, 환기가 되는 환경에 서 사료 및 상수도수를 자유급여 시켰다.

\section{이유자돈}

3원 교잡종(Landrace×Yorkshire×Duroc) 이유자돈 72 두를 공시하여 기본 배합 사료를 급여한 대조군에 24두, CS682를 $0.1 \%$ 첨가하고 개시체중이 대조군보다 낮은 CS682-1군과 $\mathrm{CS} 682$ 를 $0.1 \%$ 첨가하고 개시체중이 대조군보다 높은 CS682-2 군에 각각 24 마리씩 배정하였다. 시험 기간은 28 일로 $28^{\circ} \mathrm{C}$ 전 후, 상대습도 $50-70 \%, 12$ 시간의 명암주기, 환기가 되는 환경에 서 사료 및 상수도수를 자유급여 시켰다.

\section{시험물질}

본 실험에서 사용된 시료는 조선대학교 약리학 연구실에서 개발한 물질로서, 전남지방 해안에서 분리한 Nocarida sp. CS682 균주의 배양액을 먼저 연속식원심분리기를 이용하여 균사체와 배양 상등액을 분리하였다. 균사체는 제거하였으며 배양 상등액은 약 6601 를 회수하였다. 회수한 상등액은 약 $60-65^{\circ} \mathrm{C}$ 에서 감압농축하여 1001 수준으로 농축한 후 $2 \%$ 에 해당하는 옥수수전분을 첨가한 후 동결건조를 수행하였다. 동 결건조 후 분말을 얻었으며, 동결건조 후 성상, 물성개선 및 제품함량을 고려하여 옥수수전분을 첨가하여 완제동결건조 된 분말을 조선대학교 약학대학에서 제공받았다.

\section{시험사료의 농도설정 및 투여}

육계의 용량설정은 랫드를 이용한 급성독성[19] 및 아급성 독성[20] 연구를 참고로 용량을 설정하였고, 군 분리는 대조군 과 실험군으로 분리하였다. 대조군은 육계용 사료만 급여하였 고, 실험군은 육계용 사료에 CS682 분말을 첨가한 후 배합기를 이용하여 $0.1 \%$ 와 $1 \%$ 농도의 균질한 첨가제 사료를 제조하여
급여하였다. 이유자돈의 농도설정은 육계실험 결과를 토대로 경제적인 농도인 $0.1 \%$ 를 선택하였다. 대조군은 자돈용 일반사 료만 급여하였다. 실험군은 대조군에 비하여 평균체중이 낮은 군 $(0.1 \% \mathrm{CS} 682-1)$ 과 높은 군 $(0.1 \% \mathrm{CS} 682-2)$ 으로 분리하였고, 자돈용 일반사료에 CS682 분말을 첨가한 후 배합기를 이용하 여 $0.1 \%$ 농도의 균질한 첨가제 사료를 제조하여 급여하였다.

\section{평가항목}

\section{육계}

일당 증체량

최종 체중은 시험 종료 시의 총 체중을 사육두수로 나누어 평균치로 나타냈고, 이 수치에서 개시 체중을 뺀 후 사육일수 로 나누어 일당 증체량을 구하였다.

일일 사료 섭취량 및 사료효율

일일 사료 섭취량은 총사료 급여량에서 잔여 사료를 감하여 사육일수로 나누어 구하였고, 일당 증체량은 사료효율은 일당 증체량을 일일 사료 섭취량으로 나누어 구하였다.

일반증상 및 사망률

실험 전 기간 동안 매일 1 회 이상 일반증상과 사망률을 관찰 하였다.

\section{부검 및 육안소견}

시험물질 투여 후 28 일째에 $\mathrm{CO}_{2}$ 로 희생시켜 방혈 치사시킨 다음 부검하여 근육(닭가슴살), 흥강 및 복강장기, 위벽점막, 뇌 등의 장기에 대하여 육안적 검사를 실시하였다.

\section{혈액학적 평가}

부검 전날 절식 시킨 후 10 마리를 군별로 무작위 선출하여 23-gauge 주사바늘로 익하정맥에서 채혈하여 헤파린 튜브에 혈액을 수집하였다. 검사항목은 red blood cells (RBC), hemoglobin (HB), hematocrit (HCT), mean corpuscular volume $(\mathrm{MCV})$, mean corpuscular hemoglobin $(\mathrm{MCH})$, mean corpuscular hemoglobin concentration (MCHC), red cell distribution width (RDW), platelet (PLT), white blood cells (WBC), neutrophils (NE), lymphocytes (LY), monocytes $(\mathrm{MO})$, eosinophils (EO), basophils (BA) 등으로 Hemavet blood analyzer (Drew Scientific Co. USA)를 이용하여 분석하 였다.

\section{이유자돈}

일당 증체량

최종 체중은 시험 종료 시의 총 체중을 사육두수로 나누어 평균치로 나타냈고, 이 수치에서 개시 체중을 뺀 후 사육일수 로 나누어 일당 증체량을 구하였다.

일일 사료 섭취량, 일일 증체량 및 사료효율

일일 사료 섭취량은 총사료 급여량에서 잔여 사료를 감하여 사육일수로 나누어 구하였다. 사료효율은 일당 증체량을 일일 
사료 섭취량으로 나누어 구하였다.

\section{일반증상 및 사망률}

실험 전 기간 동안 매일 1 회 이상 일반증상과 사망률을 관찰 하였다.

\section{결 과}

\section{육계}

\section{증체량, 사료섭취량 및 사료효율}

일당 사료섭취량은 군 간에 큰 차이를 보이지 않았으나 일 당 증체량은 대조군에 비해 CS682를 $0.1 \%, 1 \%$ 처리한 군이 각각 약 $14.7 \%$, 약 $22.2 \%$ 가 증가한 것으로 나타났다. 따라서 사료효율은 CS682를 $0.1 \%, 1 \%$ 처리한 군이 대조군에 비해 각 각 약 $16.7 \%$, 약 $22.9 \%$ 가 증가한 것으로 나타났다(Table 1, 2).

\section{일반증상 및 사망률}

시험기간 중 각 시험군의 일반증상을 관찰한 결과, 모든 군 에서 사망개체는 관찰되지 않았고(Table 3), 시험물질의 투여

Table 1. Body weights of chickens fed with CS682-containing diet

\begin{tabular}{|c|c|c|c|c|}
\hline & & \multicolumn{3}{|c|}{ Groups } \\
\hline & & Control & $0.1 \%$ CS682 & $1 \%$ CS682 \\
\hline No. of chicken & examined & 34 & 33 & 33 \\
\hline \multirow{3}{*}{$\begin{array}{c}\text { Body weight } \\
\text { (g) }\end{array}$} & Day 0 & 47.80 & 43.94 & 45.45 \\
\hline & Day 14 & 235.30 & 237.90 & 239.40 \\
\hline & Day 28 & 432.35 & 484.85 & 515.15 \\
\hline
\end{tabular}

Table 2. Feed efficiency of chickens fed with CS682-containing diet

\begin{tabular}{|c|c|c|c|}
\hline \multirow{2}{*}{ Parameters } & \multicolumn{3}{|c|}{ Groups } \\
\hline & Control & $1 \%$ CS682 & $0.1 \%$ CS682 \\
\hline Initial body weight (g/bird) & 47.80 & 43.94 & 45.45 \\
\hline Final body weight ( $\mathrm{g} /$ bird $)$ & 432.35 & 484.85 & 515.15 \\
\hline Weight gain (g/bird/day) & 13.73 & 15.75 & 16.78 \\
\hline Feed intake (g/bird/day) & 28.47 & 28.25 & 28.36 \\
\hline Feed efficiency (gain/feed) & 0.48 & 0.56 & 0.59 \\
\hline
\end{tabular}

Table 3. Mortality of chickens fed with CS682-containing diet

\begin{tabular}{lrcc}
\hline & \multicolumn{3}{c}{ Groups } \\
\cline { 2 - 4 } & Control & $0.1 \%$ & $1 \%$ \\
& CS682 & CS682 \\
\hline No. of chickens examined & 34 & 33 & 33 \\
No. of survived chickens at term & 34 & 33 & 33 \\
No. of death & 0 & 0 & 0 \\
Death rate (\%) & 0 & 0 & 0 \\
Survival rate (\%) & 100 & 100 & 100 \\
\hline
\end{tabular}

와 관련된 임상증상도 관찰되지 않았다.

\section{부검소견}

시험물질 투여 후 28 일째에 모든 동물을 부검하여 근육(닭 가슴살), 흥강, 복강장기, 위벽점막, 뇌 등의 장기를 관찰한 결 과 시험물질의 투여에 기인한 어떠한 변화도 관찰되지 않았다 (Fig. 1).

\section{혈액학적 평가}

모든 항목의 수치는 정상적인 범위에 있었으며, 군 간의 유 의적인 차이를 보이지 않았다(Table 4).

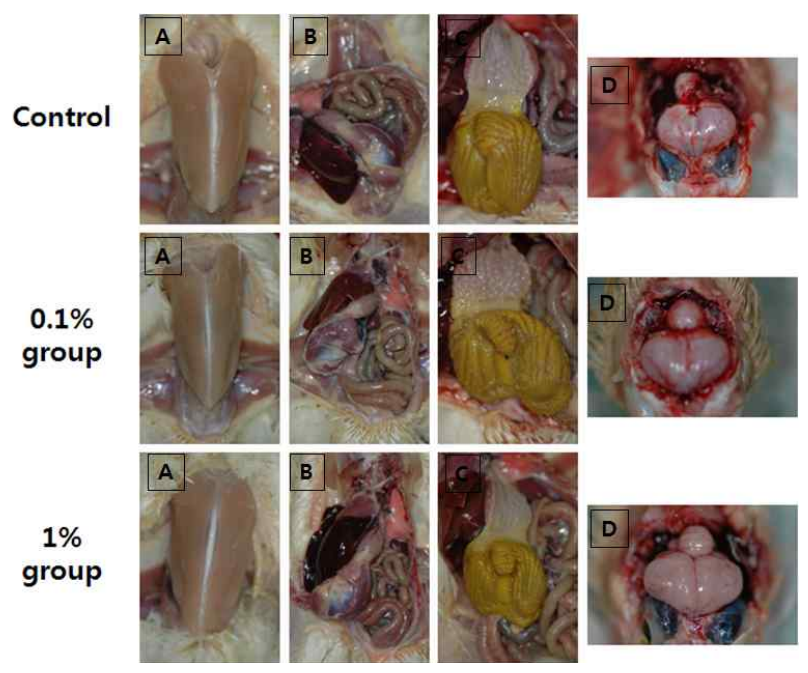

Fig. 1. Necropsy findings of chickens fed with CS682-containing diet. Treatment related gross findings were not observed at any dose tested. A: muscle, B: thoracic cavity and abdominal cavity, C: gastro-mucomembrane, D: brain.

Table 4. Hematological findings of chickens fed with CS682containing diet

\begin{tabular}{lccr}
\hline \multirow{3}{*}{ Parameters } & \multicolumn{3}{c}{ Groups } \\
\cline { 2 - 4 } & Control & $0.1 \%$ CS682 & $1 \%$ CS682 \\
\hline RBC $(\mathrm{M} / \mathrm{uL})$ & $2.92 \pm 0.24$ & $3.02 \pm 0.28$ & $2.88 \pm 0.19$ \\
$\mathrm{Hb}(\mathrm{g} / \mathrm{dl})$ & $15.14 \pm 0.72$ & $15.7 \pm 0.89$ & $15.72 \pm 1.15$ \\
$\mathrm{HCT}(\%)$ & $32.76 \pm 2.69$ & $33.51 \pm 3.10$ & $32.4 \pm 1.95$ \\
$\mathrm{WBC}(\mathrm{K} / \mathrm{uL})$ & $14.15 \pm 4.11$ & $16.61 \pm 5.35$ & $19.93 \pm 6.58$ \\
$\mathrm{NE}(\mathrm{K} / \mathrm{uL})$ & $1.58 \pm 0.81$ & $1.72 \pm 0.95$ & $3.03 \pm 1.63$ \\
$\mathrm{LY}(\mathrm{K} / \mathrm{uL})$ & $11.24 \pm 3.07$ & $13.44 \pm 4.14$ & $14.84 \pm 4.14$ \\
$\mathrm{MO}(\mathrm{K} / \mathrm{uL})$ & $1.17 \pm 0.37$ & $1.30 \pm 0.56$ & $1.77 \pm 0.67$ \\
EO (K/uL) & $0.12 \pm 0.11$ & $0.09 \pm 0.11$ & $0.26 \pm 0.19$ \\
$\mathrm{BA}(\mathrm{K} / \mathrm{uL})$ & $0.04 \pm 0.06$ & $0.01 \pm 0.02$ & $0.04 \pm 0.05$ \\
$\mathrm{PLT}(\mathrm{K} / \mathrm{ul})$ & $264.71 \pm 203.27$ & $293.1 \pm 285.12$ & $137.9 \pm 16.81$ \\
\hline
\end{tabular}

${ }^{a}$ Values are presented as mean \pm S.D.

RBC (red blood cells), Hb (hemoglobin), HCT (hematocrit), WBC (white blood cells), NE (neutrophils), LY (lymphocytes), MO (monocytes), EO (eosinophils), BA (basophils), PLT (platelet). 


\section{이유자돈}

\section{증체량, 사료섭취량 및 사료효율}

사료 섭취량은 군 간에 큰 차이를 보이지 않았고, 일당 증체 량은 $0.1 \%-1$ 군에서는 대조군보다 높은 증체량을 보였으나 큰 차이가 없었으며, $0.1 \%-2$ 군에서는 대조군보다 약 $21.6 \%$ 가 증 가하였고, 사료효율 또한 대조군보다 약 $27.0 \%$ 가 높게 나타났 다(Table 5, 6).

\section{일반증상 및 사망률}

시험기간 중 사망개체는 관찰되지 않았고, 시험물질 투여와 관련한 임상증상은 관찰되지 않았다(Table 7).

\section{고 찰}

최근 약물에 내성을 갖는 미생물이 급속히 증가하고 있어 이는 인류에 커다란 위협이 되고 있다. 항생제가 인의분야에 서 뿐만 아니라 수의분야에서도 성장 촉진제로 사용되고 있어 메치실린 저항성의 Staphylococcus aureus (MRSA)와 vancomycin 저항의 Enterococci (VRE) 출현의 주된 원인이 되고 있 다[23]. 또한 국내에서는 현재 배합사료 제조 시 lincomycin, neomycin, penicillin, colistin, bacitracin, chlortetracycline, oxytetracycline 등 7종의 항생물질을 국제보건기구 $(\mathrm{WHO})$ 를

Table 5. Body weights of pigs fed with CS682-containing diet

\begin{tabular}{|c|c|c|c|c|}
\hline & \multicolumn{3}{|c|}{ Groups } \\
\hline & & Control & $\begin{array}{c}0.1 \% \\
\text { CS682- }^{\mathrm{a}}\end{array}$ & $\begin{array}{c}0.1 \% \\
\text { CS682-2 }^{b}\end{array}$ \\
\hline No. of pigs exami & ned & 24 & 24 & 24 \\
\hline \multirow{2}{*}{ Body weight (kg) } & Day 0 & 171.5 & 154 & 190 \\
\hline & Day 28 & 417.5 & 413.5 & 494 \\
\hline
\end{tabular}

${ }^{a}$ Total body weight of this group is lighter than the control group's.

${ }^{\mathrm{b}}$ Total body weight of this group is heavier than the control group's.

Table 6. Feed efficiency of pigs fed with CS682-containing diet

\begin{tabular}{lrcc}
\hline & \multicolumn{3}{c}{ Groups } \\
\cline { 2 - 4 } Parameters & Control & $0.1 \%$ & $0.1 \%$ \\
& & CS682-1 & CS682-2 $^{\mathrm{b}}$ \\
\hline Initial body weight (kg/pig) & 7.15 & 6.42 & 7.92 \\
Final body weight (kg/pig) & 17.40 & 17.23 & 20.58 \\
Weight gain (kg/pig/day) & 0.37 & 0.39 & 0.45 \\
Feed intake (kg/pig/day) & 0.59 & 0.54 & 0.56 \\
Feed efficiency (gain/feed) & 0.63 & 0.72 & 0.80 \\
\hline
\end{tabular}

${ }^{a}$ Total body weight of this group is lighter than the control group's.

${ }^{b}$ Total body weight of this group is heavier than the control group's.
Table 7. Mortality of pigs fed with CS682-containing diet

\begin{tabular}{lccc}
\hline & \multicolumn{3}{c}{ Groups } \\
\cline { 2 - 4 } & Control & $0.1 \%$ & $0.1 \%$ \\
& CS682-1 $^{\mathrm{a}}$ & $\mathrm{CS} 682-2^{\mathrm{b}}$ \\
\hline No. of pigs examined & 24 & 24 & 24 \\
No. of survived pigs at term & 24 & 24 & 24 \\
No. of death & 0 & 0 & 0 \\
Death rate $(\%)$ & 0 & 0 & 0 \\
Survival rate $(\%)$ & 100 & 100 & 100 \\
\hline
\end{tabular}

${ }^{a}$ Total body weight of this group is lighter than the control group's.

${ }^{b}$ Total body weight of this group is heavier than ther control group's.

비롯한 국제기구의 감축권고와 잔류, 내성률이 높은 항생물질 이라는 과학적 근거를 명분으로 하여 2009년부터 배합사료용 으로는 사용금지하였고[25], 2012년부터는 배합사료에 항생제 와 항균제를 완전 사용 금지할 예정이다. 이러한 배합사료용 항생물질의 감축 정책과 안전한 축산물에 대한 소비자의 요구 는 유기산제, 면역증진제, 식물 추출물, 생균제 등의 친환경적 인 항생제 대체물질 개발에 관한 연구를 크게 증가시키고 있 다[3-5,14,15]. 그 중 생균제는 살아있는 미생물 첨가제로 장내 미생물 균형을 개선시키며 질병예방 효과가 있다고 알려져 있다[11,32]. 사료에 생균제를 첨가하였을 때 돼지의 증체량과 사료효율을 개선시켰고[16,27], 설사 발생빈도를 감소시켰다 고 보고하였다[12,30]. 또한 육계에서는 증체율을 향상시켰다 고 보고하였다[17]. 한편 23-72일령의 자돈에서 생균제를 첨가 하였을 때 일일증체량이나 사료효율에 효과가 없었다고 보고 되었으며[12], Watkins와 Kratzer에서는 가축의 생산성에 영 향을 미치지 못한다고 보고하였다[31].

Nocardia sp. CS682 (KCTC 11297BP)에서 분리된 nargenicin은 독특한 macrolide 항생제로 강력한 MRSA 항생제의 성 격을 가지고 있다[29]. Macrolide 항생제는 수의학에서 널리 사용되는 중요한 항생제로서, 호흡기 질환을 치료하거나 성장 촉진 효과로 인해 사료첨가제로 널리 사용되고 있다[6]. 또한 Sohng 등[29]에 의하면 erythromycin이나 spiramycin이 $10-20 \mathrm{mg} / \mathrm{ml}$ 에서 심한 독성을 나타낸 반면 CS682는 100 $\mathrm{mg} / \mathrm{ml}$ 의 농도에서도 독성을 나타내지 않았고 항산화작용 또 한 존재한다고 보고하였다. 따라서 본 연구는 CS682를 실제 육계와 이유자돈에 사용하였을 때 사료 첨가제로서의 효과가 있는지를 확인하기 위하여 수행하였다. 육계에서 CS682 투여 후 14 일째에는 각 군 간에 증체량 및 사료효율에서 차이가 미미하였으나, 28 일째에 일당 증체율이 대조군에 비해 $0.1 \%$ 투여 군에서 $14.7 \%, 1 \%$ 투여 군에서 $22.2 \%$ 로 증가하였고, 사 료효율은 $0.1 \%$ 투여 군에서 $16.7 \%, 1 \%$ 투여 군에서 $22.9 \%$ 로 증가하여 군 간에 큰 차이를 확인할 수 있었다. 이는 육계 사료 내 Lactobacillus sporegenes의 첨가로 증체량이 향상되었다고 
보고한 Kim 등 [19]과 육계사료와 음수 내에 Streptococcus faecium의 첨가가 항생제를 첨가한 처리군에 비하여 사료효율과 체중을 향상시켰다고 보고한 Owings 등 [26]의 연구와 유사한 결과를 보여주었다. 시험물질 투여 후 14 일째 군 간 증체량 및 사료효율의 차이가 미미했던 것은 유산균이 첨가된 사료를 계속 섭취함으로써 이들이 장내에 서서히 안착하여 장내 미생 물의 수를 증가시키고[11] 장내 세균총의 변화를 유도하여 병 원성 대장균을 감소시키며[13], 돼지에서 증체와 사료효율을 개선시켰다는 보고와도 일치하는 것으로 사료된다[27]. 또한 사망개체가 관찰되지 않고 CS682와 관련하여 특이적인 임상 증상, 부검소견 및 혈액검사 결과가 관찰되지 않았다. 이는 랫드에서 실시한 급성·아급성 독성실험에서 CS682가 매우 안 전한 물질임을 보여준 것과 일치하는 것으로 생각된다[13,28]. 따라서 육계에서 독성이 없이 증체율을 대조군보다 증가시켜 $\mathrm{CS} 682$ 가 사료첨가제로서 효과적임을 확인할 수 있었다. 육계 에서의 연구결과를 토대로 이유자돈의 예비실험에서 $0.1 \%$ 와 $1 \%$ 의 CS682를 사료에 첨가하였으나 증체율이나 사료효율에 서 군 간의 차이가 없어 실험군의 농도를 $0.1 \%$ 로 설정하였고, 더불어 $0.1 \%$ 투여군을 대조군보다 개시체중이 낮은 군과 높은 군으로 설정하여 개시체중에 따른 증체 효과를 추가로 알아보 았다. 연구결과에서는 모든 군에서 사망 개체가 관찰되지 않 았고 CS682 투여와 관련된 임상증상도 관찰되지 않아 안전성 이 확인되었다. 개시체중이 높았던 실험군의 경우, 일당 증체 량이 대조군보다 약 $21.6 \%$ 증가하여 사료효율 또한 대조군보 다 $27.0 \%$ 가 증가한 것으로 나타났다. 이는 육성돈에 있어 생균 제의 첨가가 일당 증체량과 사료 효율을 개선시켰다는 보고와 유사한 결과를 보여주었다[16]. 육계와 마찬가지로 이유자돈 에서도 CS682의 사료첨가는 독성 없이 체중증가와 사료 효율 의 개선에 효과가 있는 것으로 확인되었다.

결과적으로 육계와 이유자돈에서 CS682의 사료첨가는 생 체대사에 영향을 미치지 않고, 소화기 이상 증상을 유발하지 도 않으면서 사료효율을 효과적으로 증가시키는 것으로 나타 났다. 이와 같은 결과는 CS682가 육계 및 이유자돈에서 생체 에 부작용이 없으면서도 증체율 및 사료효율을 증가시킬 수 있는 사료첨가제로의 가능성이 있음을 제시하는 것으로 생각 된다.

\section{감사의 글}

본 연구는 2007년도 농림수산식품부산하 농림기술관리센 터(ARPC, 과제번호307014-5)의 지원으로 수행되었으며, 이에 감사드립니다.

\section{References}

1. Addison, J. B. 1984. Antibiotics in sediments and run-off waters from feedlots. Residue Rev. 92, 1-24.

2. AHI (Animal Health Institute). 2002. http://www.ahi.org/.

3. Caspar, W. 2005. Herbs and botanicals as feed additives in monogastric animals. Asian-Aust. J. Anim Sci. 16, 282-289.

4. Chen, Y. J., K. S. Son, B. J. Min, J. H. Cho, O. S. Kwon, and I. H. Kim. 2005. Effects of dietary probiotic on growth performance, nutrients digestibility, blood characteristics and fecal noxious gas content in growing pigs. Asia-Aust. J. Anim Sci. 18, 1464-1468.

5. Chiang, S. H. and W. M. Hsieh. 1995. Effect of direct-fed microorganisms on broiler growth performance and litter ammonia level. Asian-Aust. J. Anim Sci. 8, 159-162.

6. Cho, S. S., J. K. Sohng, H. J. Lee, S. J. Park, J. R. Simkhadal, and J. C. Yoo. 2009. Quantitative analysis of nargenicin in Nocardia sp. CS682 culture by high performance liquid chromatography. Arch Pharm Res. 32, 335-340,

7. Cromwell, G. L. 2002. Why and how antibiotics are used in swine production. Anim Biotechnol. 13, 7-27.

8. Dewey, C. E., B. D. Cox, B. E. Straw, E. J. Bush, and H. S. Hurd. 1997. Associations between off-label feed additives and farm size, veterinary consult use, and animal age. Prev. Vet. Med 31, 133-146.

9. Dewey, C. E., B. D. Cox, B. E. Straw, E. J. Bush, and H. S. Hurd. 1999. Use of antimicrobials in swine feeds in the United States. Swine Health Prod 7, 19-25.

10. Florea, N. F. and C. H. Nightingale. 2004. Review of the pharmacodynamics of antibiotic use in animal food production. Diagn. Microbiol. Infect. Dis. 49, 105-108.

11. Fuller, R. 1989. Probiotics in man and animals, a review. J. Appl. Bacterol. 66, 365-378.

12. Han, I. K., B. J. Chae, and S. K. Kim. 1983. The effects of feeding milk fermentation by-product and probiotics on the growing performance and prevention of diarrhea of the growing pigs. Kor. J. Anim Sci. 25, 146-152.

13. Hill, I. R., R. Kenworthy, and P. Porter. 1970. Studies of the effect of dietary lactobacilli on intestinal and urinary amines in pigs in relation to weaning and postweaning diarrhea. Res. Vet. Sci. 11, 320-326.

14. Hong, J. W., I. H. Kim, I. H. Hwang, J. H. Lee, J. H. Kim, O. S. Kwon, and S. H. Lee. 2003. Evaluation of recombinant human lactoferricin culture as a substitute for antibiotic in pig starter diets. J. Anim Sci. \& Tech 45, 537-542.

15. Hong, J. W., I. H. Kim, O. S. Kwon, J. H. Kim, B. J. Min, and W. B. Lee. 2002. Effects of dietary probiotics supplementation on growth performance and fecal gas emission in nursing and finishing pigs. J. Anim Sci. \& Tech 44, 305-314.

16. Jeon, B. S., J. H. Kwag, Y. H. Yoo, J. O. Cha, and H. S. Park. 1996. Effects of feeding enzymes, probiotics or yucca powder on pig growth and odor-generating substances in feces. Kor. J. Anim Sci. 38, 52-58.

17. Jin, L. Z., Y. W. Abdullah, and S. Jalaludin. 1998. Growth perfrmance, intestinal microbial populations, and serum cholesterol of broilers fed diets containing lactobacillus cultures. Poult. Sci. 77, 1259-1265.

18. Kanfer, I., M. F. Skinner, and R. B. Walker. 1998. Analysis 
of macrolide antibiotics. J. Chromatogr. A 812, 25-286.

19. Kim, S. H., J. C. Yoo, and T. S. Kim. 2009. Nargenicin enhances 1,25-dihydroxyvitamin D3- and all -trans retinoic acid-induced leukemia cell differentiation via PKC $\beta$ I /MAPK pathways. Biochem Pharm 77, 1694-1701.

20. Lee, J. C., T. H. Ahn, S. S. Kang, C. J. Moon, C. S. Bae, S. H. Kim, J. C. Yoo, and J. C. Kim. 2007. Single oral dose toxicity evaluation of CS682, a fermentation product of Korean soil bacteria, in rats. Lab. Anim. Res. 23, 401-404.

21. MIFAFF (Ministry of Food, Agriculture, Forestry and Fisheries). 2008, http://www.mifaff.go.kr/main.tdf.

22. Min, B. J, and I. H. Kim. 2002. Effect of dietary probiotics supplementation to feed for monogastric animals. Kor. J. Org. Agri. 10, 47-60.

23. Murray, B. 1995. What can we do about vancomycin-resistant enterococci? Clin. Infect. Dis. 20, 1134-1136.

24. NASS (National Agricultural Statistics Service). 2002. http://www.usda.gov/nass.

25. National veterinary research and quarantine service. Guidelines on animal medical supplies for formula feed production. Public Notice No 2008-25, Anyang, Korea.

26. Owings, W. J., D. L. Reynolds, R. J. Hasiak, and P. R. Ferket. 1990. Influence of dietary supplementation with Streptococcus facecium M-74 on broiler body weight, feed conversion, carcass characteristics and intestinal microbial colonization.
Poult. Sci. 69, 1257-1264.

27. Pollmann, D. S., D. M. Danielson, and E. R. Peo, Jr. 1980. Effects of microbial feed additives on performance of starter and growing-finishing pigs. J. Anim Sci. 51, 577-581.

28. Shin, I. S., J. C. Lee, N. H. Park, S. S. Kang, C. J. Moon, S. H. Kim, J. C. Yoo, and J. C. Kim. 2009. Subacute toxicity study of CS682, a fermentation product of Korean soil bacteria, in rats. Lab. Anim Res. 25, 7-13.

29. Sohng, J. K., T. Yamaguchi, C. N. Seong, K. S. Baik, S. C. Park, H. J. Lee, S. Y. Jang, J. R. Simkhada, and J. C. Yoo. 2008. Production, isolation and biological activity of nargenicin from Nocardia sp. CS682. Arch Pharm Res. 31, 13391345.

30. Underdahl, N. R., A. Torres-Medina, and A. R. Dosten. 1982. Effect of Streptococcus faecium C-68 in control of Escherichia coli-induced diarrhea in gnotobiotic pigs. Am J .Vet. Res. 43, 2227-2232.

31. Watkins, B. A. and F. H. Kratzer. 1984. Drinking water treatment with a commercial preparation of a concentrated Lactobacillus culture for broiler chickens. Poult. Sci. 63, 1671-1673.

32. Xuan, Z. N, J. D. Kim, K. N. Heo, H. J. Jung, J. H. Lee, Y. K. Han, Y. Y. Kim, and I. K. Han. 2001. Study on the development of a probiotics complex for weaned pigs. Asian-Aust. J. Anim Sci. 14, 1425-1428.

\title{
초록 : 토착미생물 발효물인 CS682의 급여가 닭과 돼지의 생산성에 미치는 영향
}

\author{
김휴경 $\cdot$ 김세은 ${ }^{1} \cdot$ 심경미 ${ }^{2} \cdot$ 김종춘 $^{1} \cdot$ 배춘식 $^{1} \cdot$ 최석화 ${ }^{3} \cdot$ 강성수 $^{1}{ }^{*}$ \\ (경기도 축산위생연구소, ${ }^{1}$ 전남대학교 수의학과, ${ }^{2}$ 남부대학교 방사선학과, ${ }^{3}$ 충북대학교 수의학과)
}

CS682의 육계 및 이유자돈에서 사료첨가제로서의 기능성을 검정하기 위해 병아리에 28 일간 $0.1 \%, 1 \%$ 의 농도 로 사료에 첨가, 급여하여 질병예방기능, 성장기능, 사료효율기능 및 안전성 평가를 실시한 결과, 위장관계 기능 장애를 일으키지 않고, 생체대사에 영향을 미치지 않으면서 사료효율을 높이는 것으로 나타났다. CS682 투여 후 14 일째에는 각 군 간에 증체량 및 사료효율에서 차이가 미미하였으나, 28 일째에는 대조군에 비해 $0.1 \%$ 군은 $115.64,1 \%$ 군은 $122.49 \%$ 의 사료효율을 보여 각 군 간에 큰 차이를 나타내었다. 그리고 28 일째 각 군에서 채혈한 혈액의 기본 혈구검사를 실시한 결과 각 군 간에 유의적인 차이를 보이지 않고 모두 정상 범위를 나타낸 것으로 보아 CS682는 생체대사에 영향을 미치지 않는 것으로 보인다. 또한 이유자돈에서 28 일간 $0.1 \%$ 의 농도로 사료에 첨가, 급여하여 질병예방기능, 성장기능, 사료효율기능 및 안전성 평가를 실시한 결과에서 임상적으로 특이한 부 작용 없이 대조군에 비하여 높은 사료효율을 나타냈다. 결론적으로 육계와 이유자돈에서 CS682의 사료첨가는 생체대사에 영향을 미치지 않고, 소화기 이상 증상을 유발하지도 않으면서 사료효율을 효과적으로 증가시키는 것으로 나타났다. 본 결과를 토대로 육계 및 이유자돈에서 안전하게 증체율 및 사료효율을 증가시킬 목적으로 $\mathrm{CS} 682$ 를 사료에 첨가하는 것이 효과적일 것으로 생각된다. 